\title{
Visualization of material flow phenomenon during friction stir welding
}

\author{
Motoki HIGASHIYAMA*, Takeshi SHINODA** and Hiroaki TAKEGAMI***
}

\begin{abstract}
A lot of papers have been appeared the clarification of material flow in friction stir welding. When aluminum alloy was used, metal flow during processing is imaged by metallurgical observation after friction stir welding process. It succeeded in taking a material flow phenomenon movie during friction stir with polymer plastics in this paper. This direct observation is revealed that two whirlpools occurred while friction stir resulting influence of pin and shoulder rotation was generated frictional heat. According to the changing of tool type, location of weld imperfection was transferred into behind the tool. In the use of left screw pin, location is move over revolutional movement the end of the pin during preheating time.
\end{abstract}

(Received April 31, 2006 Accepted July 25, 2006)

Keywords: friction stir welding, material flow, polyvinyl chloride

\section{1. 緒言}

近年, 環境保護意識が強くなり, 輸送機器メーカでは省エ ネルギー化への動きが本格化している。鉄道車両メーカでは 新幹線により軽量化の時代の流れが顕著に見られ，構体にア ルミニウム合金を使用した 700 系新幹線では 0 系に比べて 3 割 程度の軽量化が実現し，それに伴って最高速度む向上した1),2)。 このように，アルミニウム合金を中心とした軽金属材料が積 極的に利用されるようになった背景として，1991年に発明さ れた摩擦攪拌接合（Friction Stir Welding/FSW）が，それら材 料の接合を容易にさせたことが挙げられる。それまでアルミ ニウム合金の溶接は主として溶融溶接が利用されてきたが, 熱膨張係数が大きいことから溶接変形が大きく，また表面の 酸化膜が高融点であることから前処理が必要である等，アル ミニウム合金の溶接には多くの問題が生じていた ${ }^{3), 4)}$ 。しか し, 摩擦攪拌接合は入熱量が小さく, さらに継手効率や疲労 特性が高いことから，各メーカでは発明以後に順次導入・実 用化されてきている。この摩擦攪拌接合は発明されてわずか 15 年で最先端技術を支える接合に利用されており, 各輸送機 器メーカのニーズを大いに満たしていることは間違いない。 しかし, 応用技術が先行し過ぎているために基礎研究があま り行われていないのが現状である。

摩擦攪拌接合の基礎研究は, トルクと接合荷重, 入熱量の 算出, 温度分布, 熱影響部の組織観察, 流動現象解明の 5 つ に大別できるが, 流動現象について述べられた論文は, 各種 パラメータに大きく依存しているため, その他の基礎研究論
文に比べて報告が少ない。また，それら論文はアルミニウム 合金にトレーサ等を埋込み, 摩擦攪拌接合を行い, 接合後に 断面を観察することにより流動現象を観察している5)。しか し, この方法では摩擦攪拌後の流動状態を観察することしか できない。本研究ではアルミニウム合金を使用するのではな く, 透明な高分子材料を用いて摩擦攪拌中の流動現象を動的 に観察することにした。つまり，これまでの間接的な観察で はなく, 直接的観察を行うことで流動現象解明を試みた。

\section{2. 実験方法}

\section{1 実験装置}

本研究では日東制機株式会社製の摩擦圧接機を使用した。 この装置は $11 \mathrm{~kW}$ の AC サーボモータにより推力 980 98060 N を与えることができ, $37 \mathrm{~kW}$ の AC サーボモータで主軸回転 数 100 4000 rpm を与えることができる。また，接合に必要 なスライドテーブル式平行移動台はモー夕制御のあのを用い た。移動台は加工中の荷重に十分耐えられるものである。

\section{2 供試材}

ッールには直径 $20 \mathrm{~mm}$, 長さ $135 \mathrm{~mm}$ の SUS316 のステンレ ス鋼を使用した。ピン長は $5.0 \mathrm{~mm}$ とし M5 のネジで加工し た。また, ショルダ部にはばりの排出を抑制するための加工 を施している。透明高分子材料には, 予備実験より最む良好 な流動を示したポリ塩化ビニル（Polyvinyl Chloride/PVC）を 用いた。PVCの主な物性值は, 軟化点: $349 \mathrm{~K}$, 透過率 : $85 \%$, 熱伝導率： $0.17 \mathrm{~W} / \mathrm{mK}$, 伸び： $80 \%$, 引張強さ： $75 \mathrm{MPa}$ であり, FSW が適用される代表的なアルミニウム合

*名古屋大学大学院生（† 464-8603 愛知県名古屋市千種区不老町)。Graduate Student, Nagoya University (Furo-cho, Chikusa-ku, Nagoya-shi, Aichi 464-8603).

**名古屋大学大学院工学研究科 (名古屋市)〔現在：光生アルミニューム工業(㑣)（豊田市)〕。Graduate school of Engineering, Nagoya University (Nagoya-shi, Aichi) [KOSEI ALUMINUM CO., LTD. (Toyota-shi, Aichi)].

*** 名古屋大学大学院工学研究科〔現在 : 名古屋工業大学 (名古屋市)〕。Graduate school of Engineering, Nagoya University (Present: Nagoya Institute of Technology (Nagoya-shi, Aichi)]. 
金である6061-T6 材では融点： $925 \mathrm{~K}$, 熱伝導率： $0.17 \mathrm{~W} / \mathrm{mK}$, 伸び： $12 \%$, 引張強さ： $310 \mathrm{MPa}$ である。このように, 両者 の物性值は大きく異なっており，金属における FSW 条件を そのまま当てはめても流動現象の観察は行えない。しかしな がら，FSWにおいては塑性流動が接合に重要であり，PVCに おいても欠陥のない接合部が得られるならば，基本的な流動 現象は金属における FSW と同様であると考えられる。本研 究では，予備実験により PVC が良好な流動性を示す条件が得 られており，FSW 条件は限定されるものの，流動現象の解明 に PVCを用いることが可能であると考えた。PVCは, $30 \times 100 \times$ 厚さ $38 \mathrm{~mm}$ のブロックを用いた。FSW は通常板材 の突合せ接合に用いられるが，本研究では透明材料を用いた 流動現象の直接観察を目的としたため，接合部を設けず，良 好な流動を得られやすい単一ブロックへの FSW を行い，流 動現象を観察した。

\section{3 拘束条件・観察方法}

高分子材料の拘束条件ならびに観察方法を Fig. 1 に示す。 PVC ブロックに穴を開け，L字型金具とボルトを用いて横移 動テーブルに固定した。また，撮影にはDVD ビデオカメラ を使用し，摩擦攪拌中の状況を Retreating side (RS) からピン 周辺を中心に撮影した。高分子材料を使用することにより， PVC の RS 側面からピン周辺までの可視化は可能となったが, 透明材料であるためにピン周りの材料がどのように流動して いるかが観察できない。したがって，観察可能となるように 本研究ではPVC を加熱して脱塩酸分解することによって得ら れた黒色分解生成物を実験前にツールへ付着させておき, ッールの攪找状況を明確化させた。

\section{4 実験条件}

実験条件を Table 1 に示す。加工条件は, 主軸回転数を $750 \mathrm{rpm}$, 加工速度を $1.5 \mathrm{~mm} / \mathrm{s}$, 前進角を $3^{\circ}$ とした。ッール のショルダ部が PVC 表面に接してから $2 \mathrm{~s}$ 間を予熱時間とし, $2 \mathrm{~s}$ 経過後に PVC を固定したテーブルの移動を開始した。ま た，ッール形状による变化を調べるため，ピンに右㸚じと左 ねじの加工を施した 2 種類のッールを使用した。

\section{5 温度測定}

PVC を用いた摩擦攪挥接合において, 加工中の PVCの状 態を調查するため, 温度測定を行った。測定には $\phi 0.3 \mathrm{~mm} の$ アルメル・クロメル熱電対を用いた。測定位置は, ッール中 心から Advancing side (AS), RS 方向へそれぞれ $5.0 \mathrm{~mm}, \mathrm{PVC}$ 表面から深さ方向へ $1.0 \mathrm{~mm}$ の位置とした。加工条件につい ては前項と同じである。

\section{3. 実験結果および考察}

\section{1 右ねじにおける流動観察}

本研究において，撮影した動画を見ながら説明を行うこと が摩擦攪拌接合の流動現象の理解を深める最善の策である。 しかし, 本論文は紙面のみでの発表であるため, 動画の情報 はない。

右ねじッールを使用して実験を行った結果を Fig. 2 に示 す。これは撮影した動画を画像に変換したものである。ピン 先端が PVC と接するときを $t=0[\mathrm{~s}]$ とし, 各々の画像の右下 に経過時間を記し，その時間までにッールが回転した回数を 右上に記している。PVCの透明度が高く，これらの静止画で は流動を観察することが困難であるため，参考として特定の

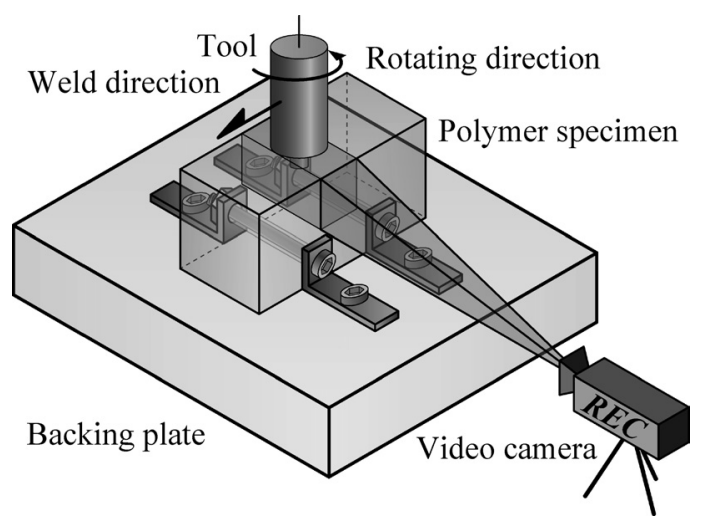

Fig. 1 Observation system for visualization of FSW using PVC.

Table 1 Friction stir welding conditions

\begin{tabular}{l|c}
\hline \hline Rotational speed, $N[\mathrm{rpm}]$ & 750 \\
Weld speed, $f[\mathrm{~mm} / \mathrm{s}]$ & 1.5 \\
Tilt angle, $\theta$ [deg.] & 3.0 \\
\hline
\end{tabular}

1つのトレーサの各時間での位置を矢印で示している。ピン 挿入から 3.32 秒後にはショルダが PVC と接し, 2 秒間の予熱 が始まる。静止画では確認が困難であるが, 動画による観察 において予熱段階（3.32５.34 秒）からピン周りでの塑性流動 が確認できている。このとき主軸回転による摩擦熱がピン・ ショルダ周辺で発生し, ピン周辺とショルダ下部の PVC が軟 化する。軟化したPVCは, 右衿じ効果によりピン周辺の材料 は下向きの力を受ける。したがって予熱時にピン先端付近で 欠陷は発生しない。また, 加工精度の悪いッールを用いた場 合（ピンがッールの中心に付いていない等）であっても，欠 陥は埋められる傾向にある。ピンが PVC と接してから 6.24 秒 後には黒色トレーサが観察された。これらのトレーサはツー ル前方より RS を迂回して後方へ回された材料であり, 左回 転するピンの影響を受けてピン後方では右回りの回転運動を する。本実験の場合, 前進角を $3^{\circ}$ 設けているため, 回転渦 の軸が $3^{\circ}$ 傾いている（Fig. 3)。よって若干の上下運動はあ るものの, トレーサは 1 回転すると元の位置に戻ってくるた め，この渦による上下方向の大きな攪拌は期待できない。ま た,この渦の回転はピンの回転の影響を受けて発生している ため, 回転半径はピンよりあ小さく, 速度の遅い渦である。

ピンが挿入されてから 10.47 秒後にはショルダの影響を受 けるようになる。ショルダでは, 内周より外周の方が周速度 が速くなるため, 中心部より外周部の方が PVC に与える影響 が大きくなる。ピン後方で回転している渦は, 水平方向に回 転運動しているため, ショルダの影響は受けていないが, ッールが前進するにつれショルダの影響を受けるため, 卜 レーサは縦回転の流動をし始める。よって 10.47〜10.68 秒で 見られるように, 接合方向に平行な軸を持つ渦により, 攪拌 されるようになる。さらに, 本実験では前進角を $3^{\circ}$ 設けてい ることで, 前進角 $0^{\circ}$ の場合よりもさらに大きな攪拌力を与 えている。これはPVC の中に見られるトレーサの流速によっ ても判断できる。ピン後方の渦は, 半径 $1.9 \mathrm{~mm}$, 流速 $9.61 \mathrm{~mm} / \mathrm{s}$ であるのに対し, ショルダ下部の渦は, 半径 $5.0 \mathrm{~mm}$, 流速 $20.5 \mathrm{~mm} / \mathrm{s}$ である。よってショルダ外周部は, 内周部に 

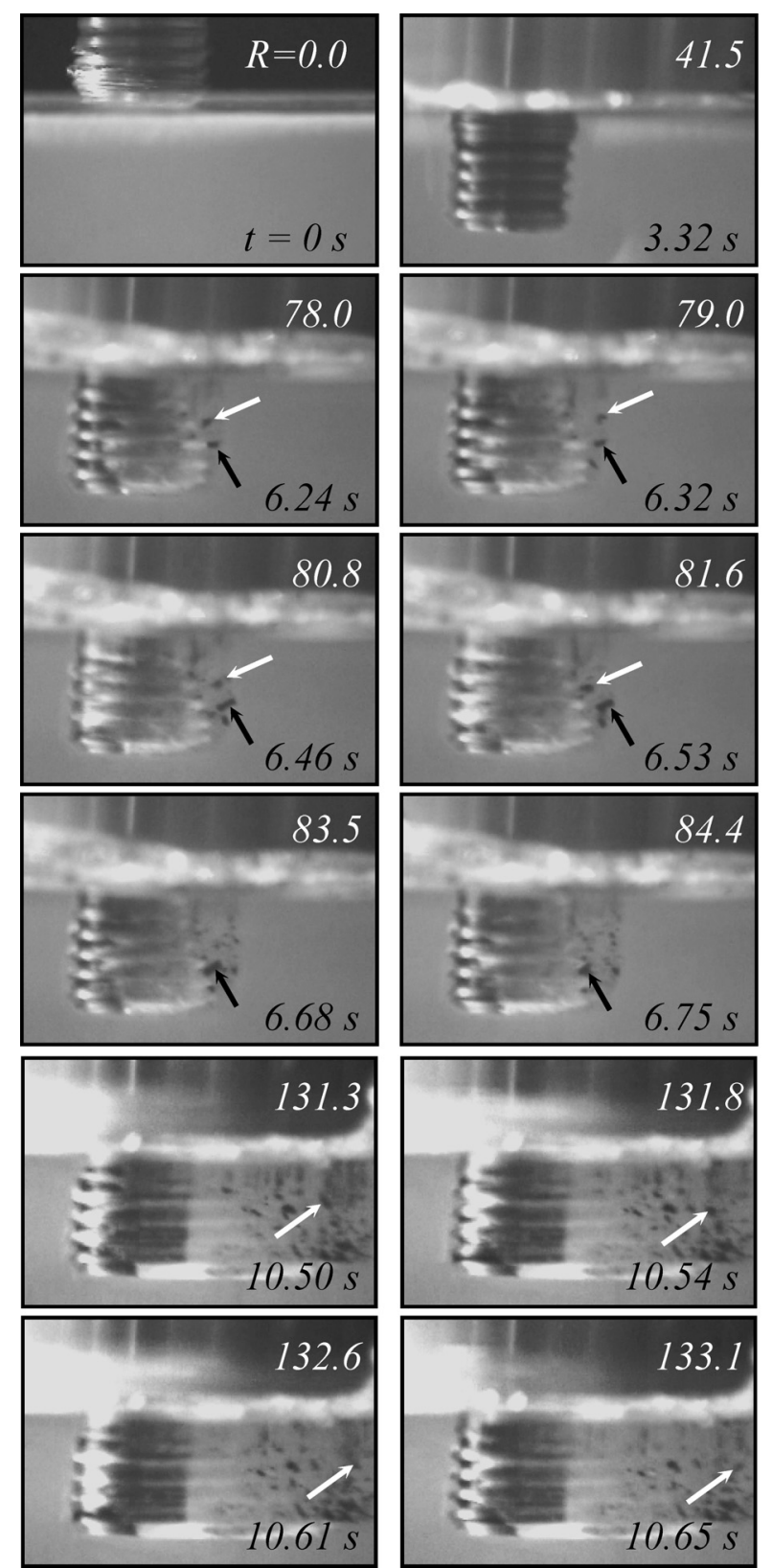
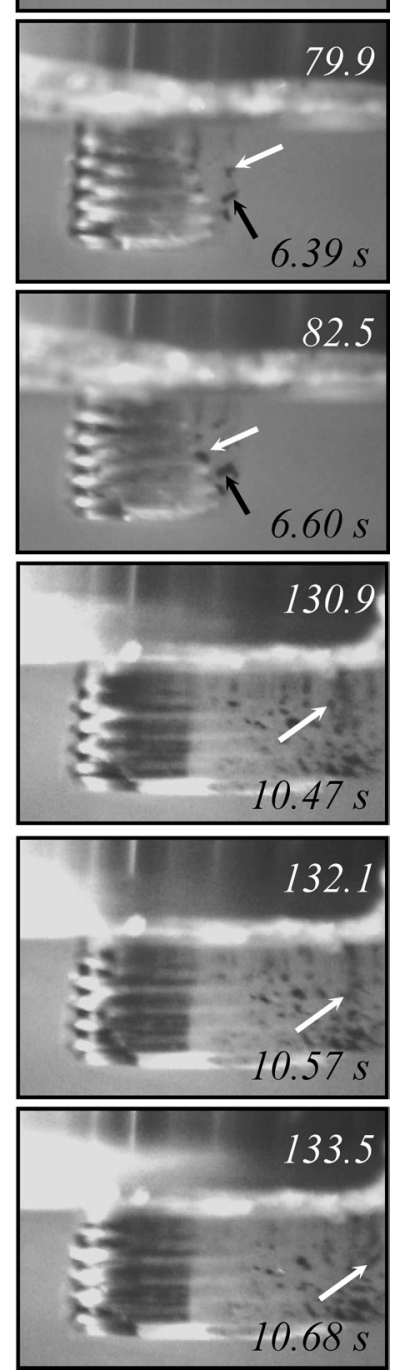

Fig. 2 Material flow in PVC during FSW (Right hand screw). $t$ : time, $R$ : number of revolutions

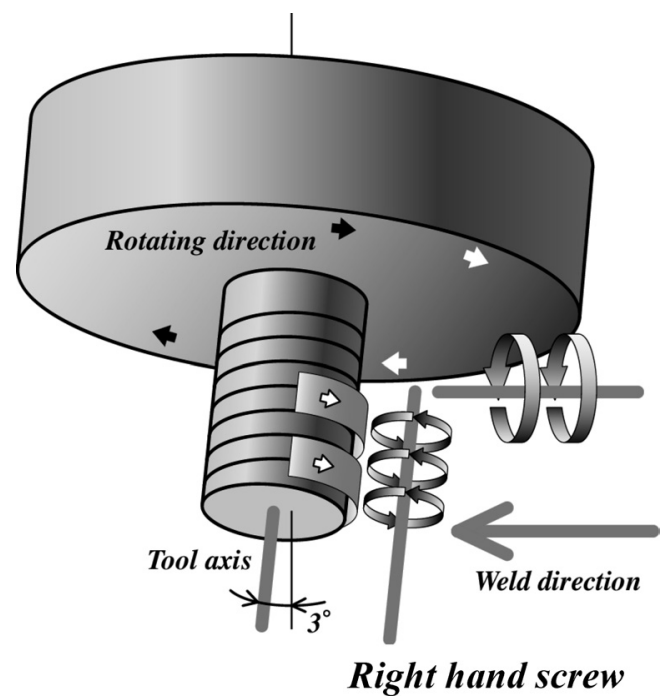

Fig. 3 Schematic illustration of material flow in PVC (Right hand screw pin tool).
比べ覺拌力が強いということがわかる。また， ショルダ外周 部は摩擦熱が発生しやすいため, 材料が軟化しやすく, 流動 が積極的に行われ，流速が速くなっていると考えられる。

加工後半にはピン先端で欠陥が発生し始めている。これは ショルダに比べてピン先端では摩擦熱が発生しにくいため, ショルダよりも早く欠陷が発生しているものと考えられる。

\section{2 左ねじにおける流動観察}

左衿ヅッールを用いて実験を行った結果を Fig. 4 に示す。 右ねじ同様，ピンが PVC と接したときを $t=0[\mathrm{~s}]$ とする。 3.15 秒後にはショルダが PVC と接し， 5.15 秒後には加工が開始す る。 5.15 秒後の写真を見ると, ピン先端には白い空洞が見ら れる。これはPVCとピンの間に発生した空洞である。つま り, ピン先端に欠陥が発生している。これはショルダが PVC と接してから加工が始まるまでの間（3.15〜5.15 秒）にピン周 辺の PVC は左㸚じ効果によって上向きの力を受けるため，ピ ン先端の材料が不足して欠陥が発生したと考えられる。 

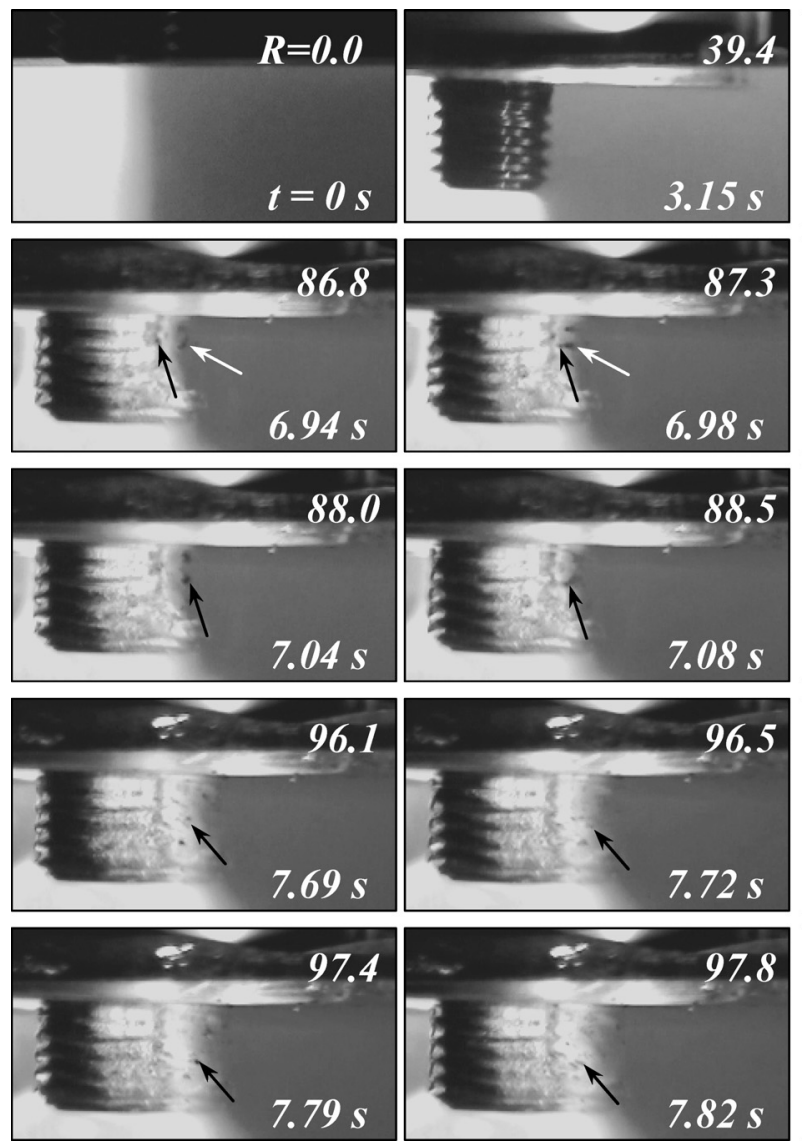
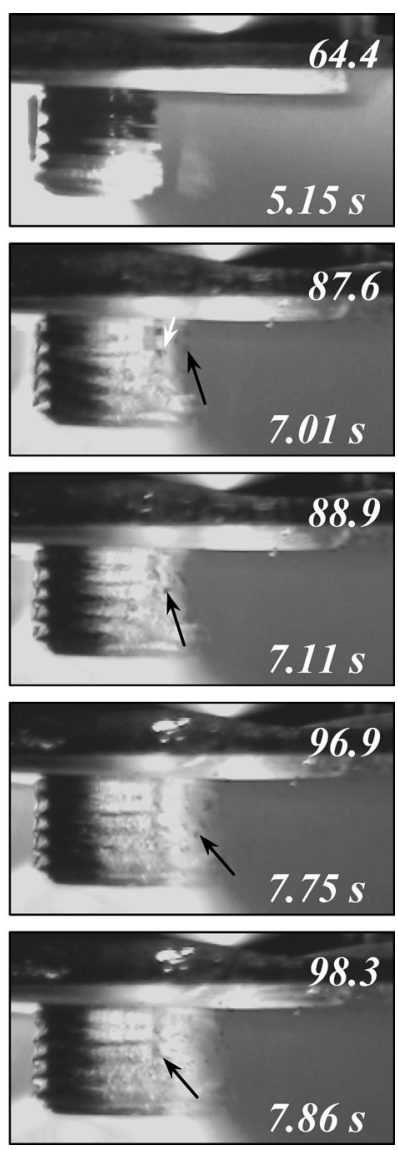

Fig. 4 Material flow in PVC during FSW (Left hand screw). $t$ : time, $R$ : number of revolutions

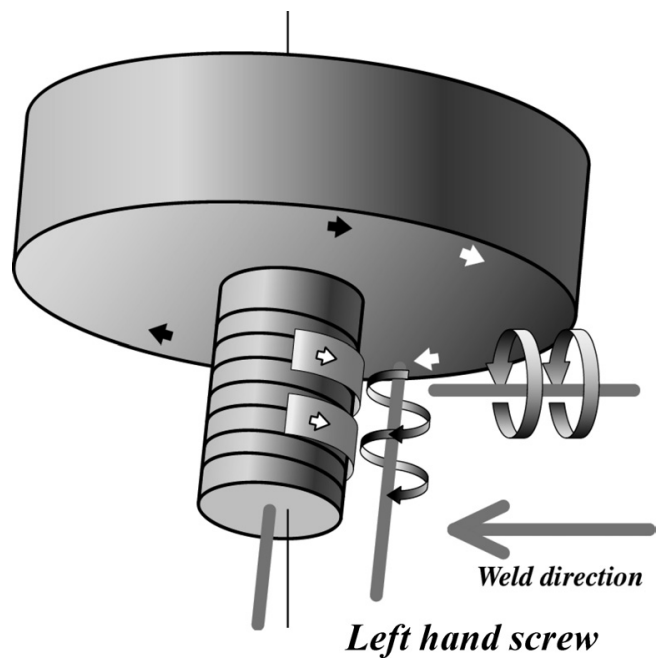

Fig. 5 Schematic illustration of material flow in PVC (Left hand screw pin tool).

加工が始まるとピン前方より RS を通り後方へ回された材 料は，欠陥を充填するように下方向へ移動する（Fig. 5）。 よって，加工が始まって数秒間は右ねじの場合と現象は異な り, 下方向の材料流動が発生する。しかしこの欠陥はすぐ充 填され， 7.69 秒後にはピン後の渦が水平方向の円運動をする ようになる。この流動は右ねじの場合と同じ現象である。さ らに加工が進み, ショルダの影響を受けるようになると, 接 合方向に平行な軸を持つ渦によって攪拌される。この渦は, 右ねじ・左ねじ同じ主軸回転におけるショルダ下の渦である

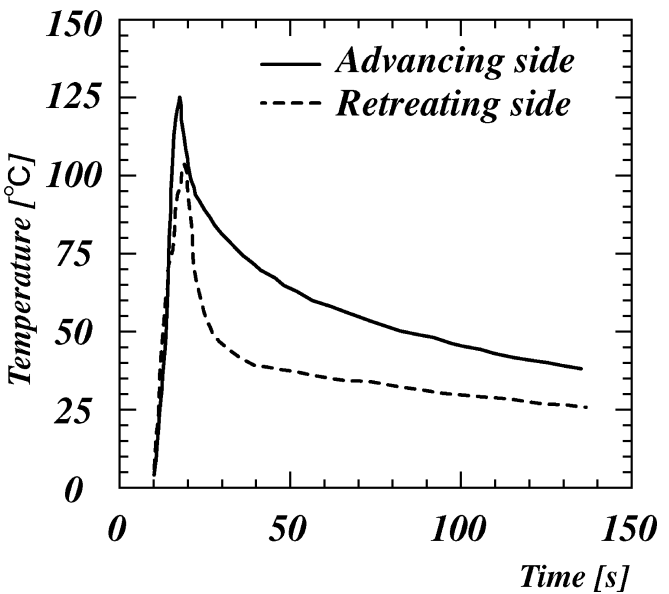

Fig. 6 Relationship between process time and temperature of FSW.

ため, 流動速度・回転半径は同じである。したがって, ショ ルダ下の渦ではピンの形状による影響はない屯のと考えられ る。

左ねじピンを使用した場合, 右ねじに比べ流動は積極的に 行われる。しかし, 予熱時に発生した欠陷は加工条件によっ て必ずしも充填することができないため, 接合の信頼性に関 してよい結果を得られないと考えられる。

\section{3 PVCにおける温度測定}

PVC 試験片を用いて温度测定を行った結果を Fig. 6 に示

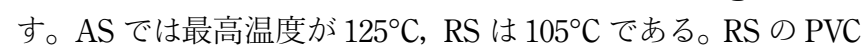
が $20^{\circ} \mathrm{C}$ 低い理由は, ッールが前進することによって常温の 
PVCがまず RSへ回り，その後，ASへ移動するためである。 つまり, AS はッールの入熱・摩擦熱によって暖められた PVC が, RS から回ってくるためである。

また PVCは， $65 \sim 85^{\circ} \mathrm{C}$ で軟化し， $120 \sim 150^{\circ} \mathrm{C}$ で可塑化す る。温度測定で得られた $\mathrm{AS}$ の $125^{\circ} \mathrm{C}$ RS の $105^{\circ} \mathrm{C}$ はともに 軟化域を超えているため, ショルダ付近の PVC は十分に軟化 している。また, $\mathrm{PVC}$ は $190^{\circ} \mathrm{C}$ を超えると塩酸を放出して分

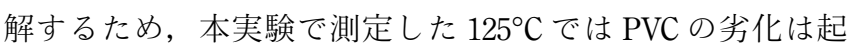
こっていない。このように, 軟化する温度は異なるが, PVC においても常温で固体の状態から温度上昇により軟化し, 流 動可能な状態になる。攪拌領域が適当な流動を示す状態にな るよう温度上昇させることにより, 金属と同等の流動現象と なると考えられる。熱伝導率等は金属と大きく異なるが, ッールおよび FSW 条件を適切に設定することにより, ッー ルによる攪拌領域での軟化の状態が金属と同様の流動を示す 状態になっていると考えられる。

\section{4. 結}

\section{言}

ポリ塩化ビニルの透明高分子材料を用いて摩擦攪拌接合の 可視化を行った結果, 以下の結論を得た。ただし, 動画によ る情報を掲載できないので, 著者の意を十分示せないことを
お詫びする。

(1) 摩擦攪拌中には 2 つ渦が発生していることが観察さ れた。1つはピン後に発生したッールに平行な軸を持つ渦で ある。他の 1 つは後方ショルダ下に発生した接合方向に平行 な軸を持つ渦である。

（2）右ねじピンを使用した場合，ピン後に発生した渦は $9.61 \mathrm{~mm} / \mathrm{s}$ の速度で右回転し, 後方ショルダ下に発生した渦は $20.5 \mathrm{~mm} / \mathrm{s}$ の速度で右回転していることが観察された。

（3）左衫じピンを使用した場合, 予熱時にピン先端で欠陷 が発生するが，加工が始まるとその欠陥は充填される。また， その後の流動は右ねじと同様である。

（4）温度測定の結果, PVC はショルダからの入熱, 主軸回 転による摩擦熱により十分に軟化しており，また，それら熱 による劣化はなく，加工前後における物質の变化はない。

\section{参 考 文 献}

1）末松 浩：溶接学会誌, 74 (2005), 10-14.

2) 古賀信次：溶接学会誌, 72 (2003), 49-52.

3）時末 光編著：FSW（摩擦攪拌接合）の基礎之応用, 日刊工 業新聞社, (2005).

4）岡村久宣：溶接学会誌， 69 (2000), 11-17.

5) Colligan: Welding Journal, 78 (1999), 229. 